\title{
Gynecomastia - evaluation and current treatment options
}

This article was published in the following Dove Press journal:

Therapeutics and Clinical Risk Management

25 March 20II

Number of times this article has been viewed

\section{Ruth E Johnson \\ Cindy A Kermott \\ $M$ Hassan Murad}

Mayo Clinic, Division of Preventive, Occupational and Aerospace Medicine, Rochester, Minnesota, USA

Date of preparation: I I th January 20 I I

Conflict of Interest: None declared
Correspondence: M Hassan Murad Mayo Clinic, Division of Preventive, Occupational and Aerospace Medicine, 200 First Street SW, Rochester,

MN 55905, USA

Tel +I 5072843097

Emailmurad.mohammad@mayo.edu
Clinical question: What is the best management approach for gynecomastia?

Results: In most patients, surgical correction usually leads to immediate cosmetic and symptomatic improvement and is considered the best approach. In men who are being treated with antiandrogen therapies, pharmacological intervention with tamoxifen is the most effective approach, followed by radiotherapy.

Implementation: Pitfalls to avoid when treating gynecomastia

- Failure to detect the very rare male breast cancer

- Overly aggressive early intervention or evaluation

- Appropriate medical intervention

- When to refer to specialist treatment

Keywords: gynecomastia, testosterone, estrogen

\section{Gynecomastia}

Definition: Gynecomastia is the benign proliferation of the glandular tissue in the male breast beneath the nipple (subareolar region). True gynecomastia is typically a rubbery or firm mound of tissue that is concentric with the nipple-areolar complex. This is to be distinguished from pseudogynecomastia, which lacks such a disk of tissue, as it is an increase in subareolar fat without enlargement of the breast glandular component. In about half of the cases, the process is clinically bilateral. Most cases are benign. Diagnostic evaluation is needed only when the palpable mass is unilateral, hard, fixed, peripheral to the nipple, or associated with nipple discharge, skin changes, or lymphadenopathy. ${ }^{1,2}$

Etiology: Gynecomastia is likely caused by an imbalance between increased estrogen activity and decreased androgen activity at the breast tissue level. Several medical conditions are associated with gynecomastia such as primary or secondary gonadal failure, androgen resistance syndromes, hyperthyroidism, chronic liver disease, use of some medications such as spironolactone, digoxin, bicalutamide, cimetidine and drugs of abuse such as alcohol and marijuana., ${ }^{1,2}$

Incidence: Prevalence of asymptomatic gynecomastia is $60 \%-90 \%$ in neonates, $50 \%-60 \%$ in adolescents, and up to $70 \%$ in men age $50-69$ years. ${ }^{3-6}$ Trimodal distribution for asymptomatic gynecomastia is noted (neonatal, pubertal, and in elderly males). Prevalence of symptomatic gynecomastia is markedly lower. 
Economics: No previous study has evaluated the economic burden of gynecomastia, but aggressive unnecessary work up in low risk cases, which are the most common, can be costly.

Level of evidence used in this summary: RCTs, systemic reviews, and observational studies.

Search sources: MEDLINE, EMBASE, the Cochrane Database of Systematic Reviews, the Cochrane Register of Controlled Trials, ISI Web of Science and Scopus.

\section{Outcomes:}

1 Identification of underlying medical conditions or associated medications

2 Resolution of breast pain
3 Cosmesis (decreased breast size)

5 Identification of the rare cases of male breast cancer

4 Resolution of psychological impact of gynecomastia

6 Avoidance of excessive laboratory and radiologic evaluation

Consumer summary: Gynecomastia is the development of glandular and ductal tissue in the male breast. It is typically caused by an imbalance of the action of estrogens (female hormones) and androgens (male hormones) on the breast tissue. A variety of medications, medical conditions and age-related factors can cause or contribute to this condition. The condition is generally benign and if it does not resolve spontaneously, can be effectively treated.

\section{The evidence}

What is the best treatment for gynecomastia in men taking antiandrogen therapies for prostate cancer?

The systematic review ${ }^{7}$ concluded that serum estrogen receptor modulators (SERMS, e.g. tamoxifen), aromatase inhibitors (AIs, e.g. anastrazole), radiotherapy (RT) or both, prevent or reduce gynecomastia and breast pain associated with antiandrogen (AA) use. Of the three options, tamoxifen is most effective.

$\begin{array}{ll}\text { Systematic reviews } & 1 \\ \text { RCTs } & 8\end{array}$

\section{Conclusions}

Serum estrogen receptor modulators, particularly tamoxifen, or radiotherapy may help prevent or reduce gynecomastia in men taking antiandrogen therapies.

What is the best treatment for gynecomastia in all other males (not taking antiandrogen therapies)?

\section{RCT}

1

Case series: multiple

No high quality evidence exists to support a role for pharmacological agents or radiotherapy in this setting. Case series showed reduction in glanular tissue size after using SERMS (e.g. tamoxifen or raloxifene).

Surgical correction is considered the gold standard treatment. Although similar to pharmacological interventions, surgical correction has been tested only in case series and not in randomized trials. Published case series demonstrates clinical success with cosmetic, symptomatic, and psychological improvements with minimal adverse effects.

\section{Surgery can be either}

1) more invasive (ie, subcutaneous mastectomy that involves the direct resection of the glandular tissue using a periareolar or transareolar approach, with or without associated liposuction).

2) less invasive techniques that require minimal surgical incision utilizing an axillary approach and endoscopic visualization and resection.

No high quality evidence exists to support one surgical approach over the other.

\section{Conclusion}

Surgery is the gold standard therapy for symptomatic gynecomastia in most patients.

\section{Summary of RCTs}

\begin{tabular}{lllll}
\hline Author & Number randomized & Population & Interventions & Results \\
\hline Ozen $^{8}$ & 125 & Men on AA & RT vs no RT & RT best; $P<0.00$ I \\
Fradet $^{9}$ & 282 & Men on AA & tamoxifen (different dosing schedules) & 20 mg/day better than smaller doses \\
Saltzstein $^{10}$ & 107 & Men on AA & tamoxifen vs anastrozole & tamoxifen better \\
Perdonà $^{11}$ & 51 & Men on AA & tamoxifen vs RT & tamoxifen better than RT \\
Di Lorenzo $^{12}$ & 102 & Men on AA & tamoxifen vs RT & tamoxifen better than RT \\
Boccardo $^{13}$ & 114 & Men on AA & tamoxifen vs anastrozole & tamoxifen better than anastrozole \\
Tyrrell $^{14}$ & 106 & Men on AA & RT vs sham RT & RT better; $P<0.00$ I \\
\hline
\end{tabular}

Abbreviations: $A A$, anti-androgen drugs; $R T$, radiotherapy 
Summary of RCTs

\begin{tabular}{llll}
\hline Author & Number randomized & Population & Results \\
\hline Plourde $^{15}$ & 80 & Boys II-I8 years & Interventions \\
\hline
\end{tabular}

Summary of selected case series

\begin{tabular}{|c|c|c|c|}
\hline Author & Sample size & Interventions & Results \\
\hline Prado $^{16}$ & 25 & minimally invasive surgery & $\begin{array}{l}\text { All had good results with no complications or need } \\
\text { for revision }\end{array}$ \\
\hline Handschin ${ }^{17}$ & 100 (160 procedures) & subcutaneous mastectomy & $\begin{array}{l}\text { All had good results, revision rate } 7 \% \text { and early } \\
\text { surgical complication rate } 31 \%\end{array}$ \\
\hline Alagaratnam ${ }^{18}$ & 61 & $40 \mathrm{mg}$ of tamoxifen daily for $\mathrm{I}-4$ months & $\begin{array}{l}80 \% \text { complete regression. No long-term side } \\
\text { effects over a follow-up of } 36 \text { months }\end{array}$ \\
\hline Lawrence $^{19}$ & 38 & 3- to 9-month course of tamoxifen or raloxifene & $\begin{array}{l}\text { Both groups had significant reduction in breast size. } \\
\text { No side effects in any patients }\end{array}$ \\
\hline Derman $^{20}$ & 37 & tamoxifen & $\begin{array}{l}\text { Pain and size reduction was seen } \\
\text { in all patients }\end{array}$ \\
\hline
\end{tabular}

\section{Decision about pursuing therapy}

Asymptomatic gynecomastia is a common and physiologic finding at three stages of the life of men and does not require intervention. Symptomatic gynecomastia in adult males can be efficiently diagnosed and reassurance and/or interventions can readily be initiated.

\section{The practice}

\section{Potential pitfalls}

- All masses that are not located in the subareolar (under the nipple) area should be evaluated further for the possibility of male breast cancer.

- Pseudogynecomastia (the presence of fatty tissue only in the breasts) associated with obesity, does not require evaluation or treatment.

\section{Management}

Gynecomastia can generally be managed by non-specialists. Indications for specialist referral are given below.

\section{Assessment}

A thorough history and physical examination should exclude pseudogynecomastia. History should include all medications, supplements, hormones, and drugs of abuse including alcohol and marijuana. Diagnostic evaluation is needed only when the palpable mass is unilateral, hard, fixed, peripheral to the nipple, or associated with nipple discharge, skin changes, or lymphadenopathy.

- If a mass is palpated in an eccentric area (non-subareolar), mammography is quite accurate in distinguishing malignant from benign male breast disease and substantially reduces the need for biopsy. Sensitivity and
In general, the decision to treat gynecomastia depends on the values and preferences of the patient and on the impact of gynecomastia on their quality of life. If no improvement is noted after the withdrawal of causative medications or treatment of the associated underlying medical conditions, surgical correction, pharmacological therapies, or radiotherapy can be considered. specificity of mammography for benign and malignant breast conditions exceeds $90 \%$.

- If palpable scrotal mass is present, scrotal ultrasound imaging is recommended.

- Basic laboratory evaluation includes blood profile for liver, kidney, and thyroid function to exclude respective medical conditions. Hormonal blood levels for total and bioavailable testosterone, estradiol, prolactin, leuteinizing hormone, and human chorionic gonadotropin can direct evaluation toward pituitary, gonadal, or extra gonadal endocrinopathies and neoplasms.

- If all testing is unrevealing, idiopathic gynecomastia is diagnosed.

\section{Treatment}

Gynecomastia is a benign condition and usually self-limited.

- Over time fibrotic tissue replaces symptomatic proliferation of glandular tissue and tenderness resolves.

- If history, physical, and lab studies do not reveal an underlying pathology, reassurance and periodic follow-up are recommended.

- Causative medications or supplements should be withdrawn and underlying causative medical conditions, e.g. hyperthyroidism, should be addressed as a first step. 
- If gynecomastia persists and is associated with pain and/or psychological distress and the patient wishes to pursue treatment, pharmacologic and surgical options are available.

- Pharmacologic therapy is likely beneficial if implemented in the first several months before fibrous tissue replaces glandular tissue, a process that is irreversible.

- The efficacy of pharmacotherapy is supported by low quality evidence SERMs, e.g. tamoxifen or raloxifene, and more recently aromataste inhibitors, e.g. anastrozole.

- Surgical correction in benign gynecomastia is done primarily for cosmetic indications (see indications for specialist referral).

\section{Indications for specialist referral}

- Patient has significant persistent bilateral or asymmetric unilateral breast development of cosmetic concern.

- Further enlargement of the male breast despite appropriate medical intervention.

- Psychological distress for patient due to breast appearance.

\section{Further reading}

1. Braunstein GD. Clinical practice. Gynecomastia. $N$ Engl J Med. 2007;357:1229-1237.

2. Johnson RE, Murad MH. Gynecomastia: pathophysiology, evaluation, and management. Mayo Clin Proc. 2009;84:1010-1015.

\section{References}

1. Braunstein GD. Clinical practice. Gynecomastia. $N$ Engl J Med. 2007;357:1229-1237.

2. Johnson RE, Murad MH. Gynecomastia: pathophysiology, evaluation, and management. Mayo Clin Proc. 2009;84:1010-1015.

3. Georgiadis E, Papandreou L, Evangelopoulou C, et al. Incidence of gynaecomastia in 954 young males and its relationship to somatometric parameters. Ann Hum Biol. 1994;21:579-587.

4. McKiernan JF, Hull D. Breast development in the newborn. Arch Dis Child. 1981;56:525-529.

5. Niewoehner CB, Nuttal FQ. Gynecomastia in a hospitalized male population. Am J Med. 1984;77:633-638.
6. Nordt CA, DiVasta AD. Gynecomastia in adolescents. Curr Opin Pediatr. 2008;20:375-382.

7. Di Lorenzo G, Autorino R, Perdona S, De Placido S. Management of gynaecomastia in patients with prostate cancer: a systematic review. Lancet Oncol. 2005;6:972-979.

8. Ozen H, Akyol F, Toktas G, et al. Is prophylactic breast radiotherapy necessary in all patients with prostate cancer and gynecomastia and/or breast pain? J Urol. 2010;184:519-524.

9. Fradet Y, Egerdie B, Andersen M, et al. Tamoxifen as prophylaxis for prevention of gynaecomastia and breast pain associated with bicalutamide $150 \mathrm{mg}$ monotherapy in patients with prostate cancer: a randomised, placebo-controlled, dose-response study. Eur Urol. 2007;52: 106-115.

10. Saltzstein D, Sieber P, Morris T, Gallo J. Prevention and management of bicalutamide-induced gynecomastia and breast pain: randomized endocrinologic and clinical studies with tamoxifen and anastrozole. Prostate cancer prostatic dis. 2005;8:75-83.

11. Perdonà $\mathrm{S}$, Autorino $\mathrm{R}$, De Placido $\mathrm{S}$, et al. Efficacy of tamoxifen and radiotherapy for prevention and treatment of gynaecomastia and breast pain caused by bicalutamide in prostate cancer: a randomized controlled trial. Lancet Oncol. 2005;6:295-300.

12. Di Lorenzo G, Perdoná S, De Placido S, et al. Gynecomastia and breast pain induced by adjuvant therapy with bicalutamide after radical prostatectomy in patients with prostate cancer: the role of tamoxifen and radiotherapy. J Urol. 2005;174:2197-2203.

13. Boccardo F, Rubagotti A, Battaglia M, et al. Evaluation of tamoxifen and anastrozole in the prevention of gynecomastia and breast pain induced by bicalutamide monotherapy of prostate cancer. J Clin Oncol. 2005;23:808-815.

14. Tyrrell CJ, Payne H, Tammela TLJ, et al. Prophylactic breast irradiation with a single dose of electron beam radiotherapy ( $10 \mathrm{GY})$ significantly reduces the incidence of bicalutamide-induced gynecomastia. Int $J$ Radiat Oncol Biol Phys. 2004;60:476-483.

15. Plourde PV, Reiter EO, Jou H-C, et al. Safety and efficacy of anastrozole for the treatment of pubertal gynecomastia: a randomized, doubleblind, placebo-controlled trial. J Clin Endocrinol Metab. 2004;89: 4428-4433.

16. Prado AC, Castillo PF. Minimal surgical access to treat gynecomastia with the use of a power-assisted arthroscopic-endoscopic cartilage shaver. Plast Reconstr Surg. 2005;115:939-942.

17. Handschin AE, Bietry D, Husler R, Banic A, Constantinescu M. Surgical management of gynecomastia--a 10-year analysis. World $J$ Surg. 2008;32:38-44.

18. Alagaratnam TT. Idiopathic gynecomastia treated with tamoxifen: a preliminary report. Clin Ther. 1987;9:483-487.

19. Lawrence SE, Faught KA, Vethamuthu J, Lawson ML. Beneficial effects of raloxifene and tamoxifen in the treatment of pubertal gynecomastia. [see comment]. J Pediatr. 2004;145:71-76.

20. Derman O, Kanbur NO, Kutluk T. Tamoxifen treatment for pubertal gynecomastia. Int J Adolesc Med Health. 2003;15:359-363.
Therapeutics and Clinical Risk Management

\section{Publish your work in this journal}

Therapeutics and Clinical Risk Management is an international, peerreviewed journal of clinical therapeutics and risk management, focusing on concise rapid reporting of clinical studies in all therapeutic areas, outcomes, safety, and programs for the effective, safe, and sustained use of medicines. This journal is indexed on PubMed Central, CAS,

\section{Dovepress}

EMBase, Scopus and the Elsevier Bibliographic databases. The manuscript management system is completely online and includes a very quick and fair peer-review system, which is all easy to use. Visit $\mathrm{http}: / /$ www.dovepress.com/testimonials.php to read real quotes from published authors. 